\title{
The Heraldry of the Cumberland Statesmen
}

\section{R. S. Ferguson F.S.A.}

To cite this article: R. S. Ferguson F.S.A. (1891) The Heraldry of the Cumberland Statesmen, Archaeological Journal, 48:1, 77-82, DOI: $\underline{10.1080 / 00665983.1891 .10852466}$

To link to this article: http://dx.doi.org/10.1080/00665983.1891.10852466

曲 Published online: 15 Jul 2014.

Submit your article to this journal $₫$

Q View related articles $₫$ 


\section{THE HERALDRY OF THE CUMBERLAND STATESMEN.}

By R. S. FERGTISON, F.S.A., (Chancellor of Carlisle).

The "statesmen" or small landed proprietors in tho north of Cumberland, now alas few and dwindling in number, yielded to none in pride of pedigree; they boasted their family arms as proudly as ever did Dacre or Howard. Herald, there was none to say them nay : bold man must have been any official of the College of Arms to venture into Bewcastle and to meddle with the tombstones of the Armstrongs and the Routledges, and the strange armorial achievements sculptured thereon. His probable fate would have been to be "spatchcocked" with his head in a rabbit hole, and his legs pinned down with a stake. ${ }^{1}$ The favourite place for the display of these armorial achievements during the last and early part of the present century was the parish churchyard, and the back of the tombstones rather than the front was the place most affected: this was done with the economical motive of leaving as much space as possible on the front of the stone, available for the purpose of recording the deaths of connections of the person to whom the stone was originally erected, though buried in distant places, even far over the sea. Thus in the churchyard of Arthuret in Cumberland, is a tombstone on whose front is the following :-

$$
\begin{gathered}
\text { In memory of } \\
\text { Margaret wife of William Ferguson of } \\
\text { Bush-on-Line who died Aug. 5th } 1745 \\
\text { Aged } 32 \text { years and also the above named } \\
\text { William Ferguson who died Sept. 13, 1804, } \\
\Lambda \text { ged } 94 \text { years. Also John Ferguson, } \\
\text { of Westlinton his Brother who died } \\
\text { Dec 15th } 1785 \text { aged } 79 \text { years. }
\end{gathered}
$$

On the baek of the stone is an achievement of arms boldly carved in high relief and in good preservation-Three human heasts, 2, 1. Crest, on a wreath on a full-faced and grated helmet, a fleur-de-lis. That this achievement of arms does not belong to any family of Ferguson within my knowledge is nothing to the point: when "Willie Fargison of the Bush-on-Lyne," as his neighbours called him, erected this monuunent to his wife he put on its back her family arms, and not his; who she was is not known, but in all probability a Hewheart, or Hewart from the neighbouring parish of Stapleton, who bore hearts on their shield. He thus left plenty of room for himself and any other members of the family tn be commemorated at some future date. To some, the

1 The writer can recollect this being done to a troublesome gamekeeper : he died. 
thus using his wife's family arms, without impaling them with his own, may seem contrary to the rules and practice of heraldry, but the characteristics of the heraldry of the "statesmen " is its freedom from all rules and practice ; they did as they pleased, tempered by the ignorance of the stonemasolı.

Thus certain families were associated with certain charges in their shields, e.g., Graham of Esk and Netherby bears $\mathrm{Or}$, on a chief $\mathrm{Sa}_{1} 3$ escallops of the field. The essentials are the escallops and all else can be dispensed with, as on a monument at Kirklinton to a Graham, where are three escallops, 1, 2, no shield at all, notbing, simply three escallops carved on the stone. In the same churchyard a monument to Edward Graham of Moorhouse, 1753, shows tho three escallops in chief and a very narrow fess below them (probably intended as the lower edge of the chief), all within a shield like a horse shoe, formed by a ribbon whose ends hang loose and are connected by a crest wreath, which is below the shield instead of above it. This same device is adopted by another Graham in the same churchyard, with the addition of a boar's head (pig's face better expresses the object), over a four leaved flower in the lower part of the horse shoe, and as a crest, a hand flourishing a whip, Some clue to these additions may be found on a neighbouring stone, on which is :-

\author{
Heres lies the body of \\ Janie Graham daughter of \\ Gracie and John born \\ Saughtrees in $1751 .^{1}$
}

And a "square shield" 2 on which a fess charged with three roundels, and in chief a circular object which may be a rose or a catherine wheel, or anything, but probably is the stonemason's version of the flower in the third Graham monument just mentioned, as the three roundels are his version of the Graham escallops. The boar's head, or pig's face appears here as a crest, turned to the sinister. These last two instances point to a marriage between a Graham and a member of a family, associated in the local mind with the bearing of a boar's head, or a boar, possible a Chamber of Wolsty, in Holm Cultram, whose crest was a boar, and one of whom married a bride from Bewcastle. (See Nicolson's Visitation of the Diocese of Carlisle p. 25). The crest of a hand brandishing a whip may be some personal allusion.

Mention has already been made of the hearts carried by Hewheart, or Hewart, thus in Stapleton churchyard on a stone dated 1727, Hewart displays a shield on which two swords crossed in saltire between three seven-petalled-roses (?) and three hearts in chief. This looks like a composite coat, recording an alliance between Hewart and some family that bore the crossed swords : it was adopted by the late Sir Simon Hewart, of Carlisle, who came from the vicinity of Stapleton, and rose to high rank as a surgeon in the Indian service; he died circa 1840. His arms are blazoned in Papworth as, Or two swords in saltire ppr hilts and pomels Sa. between two cinquefoils in fess, and another in base and three hearts in chief gu., all within a bordure az. In the same churchyard Hewheart of Linemill, displays a shield, on which is a heart pierced by an arrow head. This bears out the notion that the

1 Janie Graham clearly died young.

2 I adopt the nomenclature in Mr. Grazebrook's "Dates of Shields," his No. 7. 
original arms of Hewheart, or Hewart [or Ewart], are one or more hearts. Dodson of the Clough, in Stapleton churchyard displays an arrow liead point downwards between two hearts in base, No.7. There is probibly some connection in legend or alliance between Hewheart of Linemill, and Dodson of the Clough.

Forresters and Forsters abound in Stapleton church and churchyard. On a heavy ledger stone is :-

\title{
HOB \\ HER LIES ROBERT FORRESTER OF ST ONEGARTH SIDE 1598 IF IF.
}

The arms of Forrester or Forster of Stone, or Stane garth side, are :Arg. a chevron vert between three bugles $\mathrm{Sa}$, stringed Or. In the church is a stone on which is inscribed :-

\author{
Here lieth the Body of \\ Arthur Forester late of \\ Kingfield Gentleman who \\ departed this life Anno Dom. \\ August 24, 1680 \\ Aged 79 years.
}

His arms are simply a chevron ermine between three bugles, but others of the name are much more liberally dealt with in the churchward:-thus W. F. has three stags' heads caboshed in chief, three arrow heads points downwards in fess, and threo bugles in base; IF has the same, but his stags heads are in profile, and his arrow heads point upwards. Nicol Johnson of Sorbys, 1758, has on his shield a chevron between three bugles, the coat of the Foresters : if not a Forester by descent, Nicol Johnson was probably one hy profession, as were the Foresters originally; it is a come-down-in-the-world, us well as in heraldry, to find on the tombstone of John Forester of Leversdale Lane End, who died December 12th, 1806, aged 22 years, a jack-plane, a pair of compasses, and a carpenter's square, enclosed with two sprigs of willow within an oval frame.

The variations between the arms carried by different families of the same name are curious - take the Routledges for instance. The essential parts of the Routledge cont of armis are a chevron, a garb, a sprig of willow and a sword, which last may be indifferently within or without the shield, either in chief, or over the shield. These seven examples at Bewcastle, which display all the charges just mentioned; they are differenced by having in base a mullet, a holly leaf, an escallop, a heart voided, a rose, a fleur-de-lis, etc. The garb, by the way, is a sore trial to the masons, who make very queer work of it -a bear's paw, a human hand: in one case it appears as a hand with proper allowance of fingers and thumb. The sword of Routledge seems copied from that of a modern officer of infancy, or rather from the tin sword of childhood.

The variants of Armstrong in Bewcastle churchyard are curious. The arms of Armstrong are three dexter arms vambraced and proper, and the crest is a dexter arm vambraced and proper. In Bewcastle churchyard, in 1762, we find these arms displayed with some attempt at heraldic accuracy, knightly helmet, and the crest thereon. Hard by is another stone on which are the arms of Armstrong, but the dexter arms are naked with clenched fists, and the knightly helmet becomes that of an 
eighteenth century dragoon. Another of the clan displays sinister arms, naked, turned to the sinister, and his helmet becomes a mere curl to the sinister. Until I saw these three coats at Bewcastle I was much puzzled by the objects I found surmounting shields of arms on tombstones in North Cumberland. Thus, for long I could make nothing of the object over the shield on the back of the Ferguson stone at Arthuret, and took it to be a bush on a mount. It was not until after I had visited Bewcastle that I recognised it as a full-faced and grated helmet, with crest wreath and crest of a fleur-de-lis. In another instance I at first took the helmet for a celestial globe and frame, such as our great grandmothers were taught the stars upon; the helmet most frequently degenerates into a simple crook, like the nead of a walking stick, or into a bird's head, as on a stone to one Noble nt Kirklington. A yet more curious variety of Noble is at Stapleton, where the helmet is degenerated into a bird's head, and the crest above it is "very like a weasel," a demiweasel rampant.

The variants of Baty are worthy of record. At Arthuret Richard Baty of Stonehouse, who died June 11,1738, has on the back of his stone a shield with nine rows of chequers; over the top of the shield is a massle between two keys fesswise, bits inwards and downwards. In Stapleton churchyard is a stone to a Baty with the same chequy shield, and over it the keys in saltire, bits uppermost and outwards. The same churchyard boasts a yery odd and modern edition of Baty. The shield ticrce in pale, and bears two mascles in chief and a third in base, also a dagger or broad-bladed knife in fess between two keys, fesswise, bits to sinister and outwards. Kirklinton possesses a very modern variant of Baty, viz, within an oval border, between three horse-shoes a hammer, and pair of pincers in saltire :-

$$
\begin{aligned}
& \text { My sledging hammer lies reclined } \\
& \text { My bellows. too, have lost their wind } \\
& \text { My fire's extinct, my forge decayed } \\
& \text { And in the dust my vice is laid } \\
& \text { My coals are spent, my iron gone } \\
& \text { My nails are driven, my work is done. } \\
& \text { Richard Baty of Redhous } \\
& 1812 \text {. }
\end{aligned}
$$

In Arthuret Churchyard is an altar tomb, on which :-

$$
\begin{gathered}
\text { Here lies the body of Mary wife of } \\
\text { David Story of Knowe, who died May } \\
\text { 6th, 1767, aged years. } \\
\text { And also of (nine more of the } \\
\text { family) }
\end{gathered}
$$

There is a coat of six pieces, 1,3 , and 5 , an ostrich-like bird passant to the sinister, probably a stork or crane, of which Story bears three; 2 , a pale floree; 4, vairee; 6, a bend. At Kirklinton Richard Story, 1746 , has a shield with three triangular objects in chief, and three birds (the storks or cranes just mentioned); the three objects may be bells, and indicate an alliarce with the family of Bell. A very curious shield to Story vceurs at Kirlslinton under date of 1697-two mullets in chief, a crescent in the honour point, and in base an object like a blunt-shaped wedge.

Some single coats yet deserve mention. At Kirklinton Luke Black, 
aged 98 , in 1738 , has his shield charged with a bend sinister chequy of five pieces, but no imputation on his fame; sinister or dexter, inside a shield or out, was all the same to the heraldic mason of North Cumberland. Carruthers of Foultown, 1783, has three fleur-de-lis, 2, 1. Irving of Jerrieston, who died September 26, 1772, has a circular shield, on which is a chevron between three holly leaves in chief, and an unknown object in base; the stone is further decorated with a skull, a pair of cross bones, and an hour-glass. Christopher Routledge has a blank shield underneath a cherub like a wooden doll. This pattern was kept in stock by masons, and instances abound. Janet, the wife of Christopher Jackson, is commemorated by a shield bearing a pair of scissors and a tailor's goose.

At Bewcastle, Scott of Cruckbarn bears, in a circular shield on a bend, a star between two crescents, the arms of Scott of Buccleuch, of whose clan he would probably be a member. Wilson bears a chevron between three roses; in chief a meek animal, which may be the wolf which figures in Wilson coats. There is a Wilson at Arthuret:-

\section{Here lyes \\ Gorg Wilson son \\ to Gorg Wilson in \\ Moot who departed \\ this life December, \\ 1693 of age 29.}

On the back of the stone is a shield with three wolves' heads coupee, crest, a crescent issuing flames of fire-the arms and crest of Wilson of Jallam Towers in Westmorland. In the same churchyard, Arthuret, is a stone with an effaced inscription, and on the back a shield, a pale charged with three roundels, a coat not known to me as a local one. The shield is of an extraordinary shape. Andrew Holliday of Hudskill, also in Arthuret churchyard charges his shield with a simple chevron; his date is effaced.

At Stapleton, Gillespie of Upper Luckens, 1718, has 'also the simple chevron. At Stapleton, also, William Carruthers bears the same shield as Carruthers of Foultoun at Kirklinton, but differenced with a mullet in the honour point. The wife of Thomas Routledge of Smithstead, 1727, has a coat of arms with three mullets in chief, and three objects (? garbs in base). A stone without inscription bears a circular shield, charged with three leopard's faces on a bend, to the sinister of which are three cocks. Three leopard's faces on a bend are Stevenson or Stephenson of Cumberland.

In the churchyard of Over-Denton are a remarkable series of monuments to one family.

Here lieth the Body of Bridget Teasdale of

Mumps hall who Died

October 7 th, 1779 aged 59 years.

On the back is a shield of arms, on which 3 piles issuing from the chief and meeting in the base point. Underneath this verse :-

Altho' in death's cold arms I make my Bed,
lonly wait until the great assize
When the last trumpet shall awake the dead.

Yo, XLVIII 
(ii.)

Here lieth the Body

of Margaret

Teasdale of Mumps

Hall who died, May

the 5 th, 1777 aged 98

years.

What I was once some may relate

What I am now is each one's fate

What I shall be none can explain

Till he that called call again.

The same coat of arms is on the back.

(iii.)

Here lieth the Body of

George Teasdale of

Mumps hall who Died Apr.

the 27 th, 1753 Aged 25 years.

Underneath same verse as on No 1, and at back same coat of arms.

(iv.)

Here lieth the Body of

John Teasdale of Mumps

hall who Died Nov. 1

1788 aged 73 years

Being the last male heir

of the Teasdales of Mumps hall,

Same coat of arms at back.

At foot of (ii.) is a flat slab nearly illegible-

(v.)

Margaret Carrick who died 4th Dec. 1717.

The second of these inscriptions commemorates a fearsome woman, Tibs Mumps of Mumps Ha, embalmed in fame by Sir Walter Scott in Guy Mannering.

Instances might easily be multiplied of statesmen's arms, viz., in Brampton churchyard the Bowmans display their three long bows, and the Hetheringtons their three griffins, on the back of their several stones. From such sources, and from lintels in farm and other houses a curious local ordinary of arms might and should be compiled, and at once for decay works havoc with tombstones and lintcls, and, since the imposition of a duty on armorial bearings, the frugal, though prond, statesmen of Cumberland have ceased to use their armorial bearings, and they are falling into oblivion.

The pedant in heraldic rules will no doubt despise the whole system, if system it may be called, but it is a survival of the early heraldic practice of combining in one shield the charges of baron and feme. Thus, when Wharton of Wharton, who bore a saltire of lions' paws in a golden field married in the time of Edward III. the heiress of Hastings of Croglin, who bore a maunche argent in a sable field, he took the lady's coat bodily, and encircled it with a border of gold charged with saltircs of lion's paws; so, when a Hewheart of Stapleton in the time of George III. married a Bell of Kirklinton, he charged his shield with his own hearts and his wife's bells. 